\title{
INHBE Gene
}

National Cancer Institute

\section{Source}

National Cancer Institute. INHBE Gene. NCI Thesaurus. Code C129846.

This gene plays a role in the regulation of hormone signaling. 